\title{
Socially sustainable degrowth as a social-ecological transformation: repoliticizing sustainability
}

\author{
Viviana Asara $^{1,2} \cdot$ Iago Otero $^{2,3} \cdot$ Federico Demaria $^{1,2} \cdot$ Esteve Corbera $^{1,4}$
}

Published online: 5 July 2015

(C) Springer Japan 2015

\section{Introduction}

In the late 1980s, the sustainable development paradigm emerged to provide a framework through which economic growth, social welfare and environmental protection could be harmonized. However, more than 30 years later, we can assert that such harmonization has proved elusive. Steffen et al. (2015) have shown that four out of nine planetary boundaries have been crossed: climate change, impacts in biosphere integrity, land-system change and altered biochemical flows are a manifestation that human activities are driving the Earth into a new state of imbalance. Meanwhile, wealth concentration and inequality have increased, particularly during the last 50 years (Piketty 2014). In 2008, the collapse of large financial institutions was prevented by the public bailout of private banks and, nowadays, low growth rates are likely to become the norm in the economic development of mature economies (Summers 2013; IMF 2015; Teulings and Baldwin 2015). The three pillars of sustainability (environment, society and economy) are thus simultaneously threatened by an intertwined crisis.

Viviana Asara

viviana.asara@gmail.com

1 Institute of Environmental Science and Technology, Universitat Autònoma de Barcelona, Barcelona, Spain

2 Research and Degrowth, Barcelona, Spain

3 Integrative Research Institute on Transformations of HumanEnvironment Systems (IRI THESys), Humboldt-Universität zu Berlin, Berlin, Germany

4 Department of Economics and Economic History, Universitat Autònoma de Barcelona, Barcelona, Spain
In an attempt to problematize the sustainable development paradigm, and its recent reincarnation in the concept of a "green economy", degrowth emerged as a paradigm that emphasizes that there is a contradiction between sustainability and economic growth (Kothari et al. 2015; Dale et al. 2015). It argues that the pathway towards a sustainable future is to be found in a democratic and redistributive downscaling of the biophysical size of the global economy (Schneider et al. 2010; D'Alisa et al. 2014). In the context of this desired transformation, it becomes imperative to explore ways in which sustainability science can explicitly and effectively address one of the root causes of social and environmental degradation worldwide, namely, the ideology and practice of economic growth. This special feature aims to do so by stressing the deeply contested and political nature of the debates around the prospects, pathways and challenges of a global transformation towards sustainability.

The 'growth' paradigm (Dale 2012; Purdey 2010) is indeed largely accepted in advanced and developing countries alike as an unquestioned imperative and naturalized need. It escapes 'the political', i.e. the contested public terrain where different imaginaries of possible socio-ecological orders compete over the symbolic and material institutionalization of these visions. In this sense, the contemporary context of neoliberal capitalism appears as a post-political space, i.e. a political formation that forecloses the political, the legitimacy of dissenting voices and positions (Swyngedouw 2007). As Swyngedouw (2014:91) argues: "the public management of things and people is hegemonically articulated around a naturalization of the need of economic growth and capitalism as the only reasonable and possible form of organization of socionatural metabolism. This foreclosure of the political in terms of at least recognizing the legitimacy of dissenting 
voices and positions constitutes a process of de-politicization. [...] (The) wider framework of neoliberal growth is in itself not contestable."

Counter-hegemonic discourses and praxis are needed to re-politicize the debate about what kind of society (and sustainability) we want to live in and to open up alternative avenues (Mouffe 2005). Degrowth aims to repoliticize the debate on the relationships between sustainability, economy and society (Kallis et al. 2014) and to advance a new vision of social-ecological transformations. It contributes to building a counter-hegemonic narrative, in alliance with equivalent alternative frameworks emerging from the global South such as Buen Vivir from Latin America (Gudynas 2011), ecological Swaraj from India (Kothari 2014) and Ubuntu from South Africa (Metz 2011).

In what follows, we present first the intellectual origins of degrowth, to explain how such a paradigm understands the question of sustainability. Special attention is paid to the social and ecological limits to growth and to the socialecological transformation envisioned by the degrowth paradigm. Next, we discuss the contents of the papers included in this Special Feature. Finally, we conclude by stressing the contribution of degrowth to sustainability science and practice, and argue for a re-politicization of the science and practice of sustainability.

\section{Degrowth}

\section{Origins and foundational scientific premises}

The concept décroissance (degrowth) was first coined by André Gorz in a debate organized by Le Nouvel Observateur in Paris in 1972, as a follow-up of the Limits to Growth report (Meadows et al. 1972; Demaria et al. 2013). Participants included philosophers Herbert Marcuse and Edgard Morin, the ecologist Edward Goldsmith and the then President of the European Commission Sicco Mansholt. Gorz employed the term to question the compatibility of the capitalist system with the "degrowth of material production", 1 and he underscored the importance of reducing consumption and promoting values like frugality, autonomy and conviviality.

Gorz's commentary exemplifies the encounter of the ecologist and culturalist critiques of economics (Latouche 2011, 2013; Bonaiuti 2013; Martinez-Alier et al. 2010). The former draws centrally on Nicholas Georgescu-Roegen's bio-economics, which relies on ecological science to

\footnotetext{
1 'The global equilibrium, for which no-growth-or even degrowth - of material production is a necessary condition, is it compatible with the survival of the (capitalist) system?' M. Bosquet (André Gorz), Nouvel Observateur, Paris, 397, 19th June 1972, p. IV.
}

challenge orthodox economics (Sorman and Giampietro 2013). The culturalist critique is inspired by 'post-development' theorists and political ecologists, who critiqued the widespread adoption of particular technologies and consumption and production models from the global North worldwide (Illich 1973, 1978; Gorz 1975, 1991, 2009; Latouche, 2009, 2011). For Bonaiuti (2008, 2013), these two lines of critical thought share similar pre-analytical premises and they antagonize with the sustainable development paradigm, which does not question the anthropological, political, cultural and institutional premises of growth economics. Indeed, Georgescu-Roegen's bio-economics unravelled the entropic nature of the economic process. While economic science was built on the mechanistic paradigm (Newton-Laplace) and on the model of classic science, the thermodynamic revolution, GeorgescuRoegen (1971) argued, should urge us to consider the fundamental element of irreversible time and the increase of entropy in a closed system. Georgescu-Roegen (1971, 2009) emphasizes the ecological limits to growth (Grinevald 2008) and his works, alongside Boulding's (1966) thesis on biophysical limitations of economic activity and Kapp's $(1961,1970)$ reframing of environmental externalities as an inherent aspect of modern consumption and production, are considered the foundations of ecological economics.

Building on ecological economics research, degrowth challenges the possibility that economic growth can be decoupled from material and energy flows (Jackson 2009; Dietz and O'Neill 2013). It is argued that even if there is some evidence for relative decoupling-e.g. world GDP has risen faster than carbon dioxide emissions over the last 18 years (Jackson 2009)—absolute decoupling, i.e. absolute decline in resource use over time while the economy grows, is not occurring (Ayres et al. 2004; Krausmann et al. 2009; Galeotti et al. 2006; Stern 2004; Soumyananda 2004). Degrowth thus challenges the possibility that some ideas, such as the dematerialization of the world's economy (UNEP 2011), ecological modernization, green growth (Martinez-Alier 2014; Latouche 2009; Gómez-Baggethun and Naredo 2015, this feature) and the circular economy (Haas et al. 2015) fulfil their promises. Additionally, degrowth calls attention to the fact that eco-efficiency gains are often re-invested in further consumption or economic activities that counterbalance the improvements achieved (Jevons' Paradox or rebound effect, Polimeni et al. 2007).

The interest for critical engagements with economic growth and development paradigms faded during the last two decades of the twentieth century, but revived with the turn of the new one (Kallis et al. 2014). A special issue in 2002 was published in the journal Silence (No. 280), and a colloquium entitled "Unmaking development, redoing the world" was held at UNESCO in Paris on that same year (Duverger 2011; 
Muraca 2013). With the organization of the first international colloquium on sustainable degrowth in Lyon in 2003, which gathered hundreds of participants from France, Switzerland and Italy, degrowth established itself as an international movement (D'Alisa et al. 2014). Degrowth became "both a banner associated with social and environmental movements and an emergent concept in academic and intellectual circles, [which] are interdependent and affect each other" (MartinezAlier et al. 2010:1742). At least five international academic conferences with civil society participation were subsequently held in Paris (2008), Barcelona (2010), Venice and Montreal (2012) and Leipzig (2014) with increasing number of participants (in Leipzig there were about 3000 participants) and the next one will be organized in Budapest in 2016. Once a marginal perspective, degrowth is starting to being referred to also in the mainstream debate. For instance, recently Paul Krugman (2014) in The New York Times noticed that "antigrowth environmentalism is a marginal position even on the Left, but it's widespread enough to call out nonetheless". Even Pope Francis (2015), in his Encyclical Laudato Si', argues that "the time has come to accept degrowth in some parts of the world, in order to provide resources for other places to experience healthy growth". ${ }^{2}$

\section{Defining principles}

As noted above, degrowth was originally placed at the junction of ecological and cultural critiques to economic growth and development, but has recently evolved to encompass also concerns on democracy, justice, meaning of life and wellbeing (Flipo 2007; Demaria et al. 2013). Degrowth has thus given birth to an incipient social movement and activist-led science and it has been depicted as "a performative fiction indicating the necessity of a rupture with the growth society" (Latouche 2013:7). Some scholars and activists have tried to define degrowth more concretely as a downscaling movement. Schneider et al. (2010:512) define it as "an equitable downscaling of production and consumption that increases human well-being and enhances ecological conditions at the local and global level, in the short and long term".

The adjective 'socially sustainable' has often accompanied the term to stress that the normative content of degrowth is overall related to the improvement of social well-being and equity, and to distinguish it from 'unsustainable degrowth', that is, from economic recessions that deteriorate social conditions (Schneider et al. 2010). The objective of degrowth is not to reduce GDP, an arbitrary indicator (Fioramonti 2013; Philipsen 2015), but to increase social justice and ecological sustainability. Therefore, degrowth should not be understood in its literal meaning (i.e. negative growth of

\footnotetext{
${ }^{2}$ Our translation from the original text in Spanish.
}

GDP) or just as shrinking of material throughput (Sekulova et al. 2013; Kallis et al. 2014). The mere shrinking of consumption and production levels by themselves would be even more deleterious than current growth systems. Growth economies do not know how to degrow: there is nothing worse than a growth society that does not grow (Latouche 2008:18; Kallis et al. 2012). Degrowth is a provocative slogan to challenge, and escape, the ideology of growth (Hamilton 2004). It is a social project or, borrowing from Bloch, a 'concrete utopia' (Muraca 2014; Latouche 2009) that envisions a deep social-ecological transformation. Emphasis is not put on 'less', but on 'different': "In a degrowth society, everything will be different: different activities, different forms and uses of energy, different relations, different gender roles, different allocations of time between paid and non-paid work and different relations with the non-human world" (Kallis et al. 2014:4).

\section{Ecological and social limits to growth}

From a degrowth perspective, the current social-ecological-economic crisis is the result of systemic limits to growth and the obsession to promote growth at all costs, including the creation of debt to fuel growth or austerity policies to restore stability (Kallis et al. 2014, 2009; Bonaiuti 2013). These tensions recall O'Connor's (1998) second contradiction of capitalism, which highlights that capitalism systematically undermines the biophysical conditions on which it depends in the pursuit of capital accumulation, although there are no automatic connections between biophysical limits, increases in costs of capital and the end of capital accumulation (Klitgaard 2013; see also Harvey 2014). However, recognizing the importance of defining ecological limits in which the economic activity should be embedded is not sufficient (Deriu 2008; Muraca 2013). On the one hand, it should be acknowledged that the ecological crisis directly stems from the 'imperial mode of living' of the global North, which is "rooted in prevailing political, economic, and cultural everyday structures" (Brand and Wissen 2012:555). Taking this into account, economic growth is not only environmentally unsustainable, but also unjust, and degrowth connects with concepts such as the recognition and reparation of ecological debt, post-extractivism and Buen Vivir (Martinez-Alier 2012; Demaria et al. 2013). On the other hand, degrowth advocates agree that ecology by itself cannot pinpoint the way or the normative ground on how to reach the desired social-ecological transformation (Muraca 2013; Deriu 2008). Degrowth aims to open up the democratic discussion of selective downscaling of man-made capital and of the institutions needed for such a 'prosperous way down' (Odum and Odum 2001). An important lesson 
taken from early political ecologists is that degrowth is about a (collective and individual) democratic movement of establishing limits within which human well-being and creativity can flourish (Muraca 2013; Kallis et al. 2014; Asara et al. 2013). The literature on autonomy emphasizes collective self-limitations, rather than (external) limits to growth, invoked not to protect nature or avoid disaster, but because simplicity, conviviality and frugality is how good life is conceived. Limits to growth therefore become "a social choice, not [...] an external imperative for environmental or other reasons" (Schneider et al. 2010:513).

Additionally, degrowth scholars are increasingly engaging with the intersection between income and wellbeing. The so-called Easterlin paradox refers to the lack of positive correlation over time between reported subjective well-being and income growth, at least for countries with sufficient means to meet basic needs (Easterlin 1974; Helliwell et al. 2012). What Max-Neef (1995) has called the 'threshold hypothesis' holds that, after a certain threshold point, economic growth does not bring about improvements in people's quality of life. Other studies have shown that income equality is conducive to better individual and collective health and happiness (Jackson 2009; Chancel et al. 2013; Pickett and Wilkinson 2009). Such emerging evidence, however, has not yet undermined the extended mantra that economic growth can be "a magic wand to achieve all sorts of goals" (Dale 2012): from soothing class tension and reducing poverty to reducing the gap between 'developed' and 'developing countries', to fostering social capital and steering environmental sustainability through 'green growth', among others.

It can be argued then that such ideological fix on economic growth stems from the naturalization of the prevailing social order in which the interests of capital are identified with the common good (Dale 2012; Purdey 2010). For example, it has been traditionally assumed that the benefits of economic growth (spurred by financial benefits accumulated by business and investors) trickle down to the poorest groups of society through a variety of means, such as employment and redistribution programs. More recently, the calls for and rhetoric of 'green growth' suggest that fostering resource efficiency measures, promoting more sustainable primary energy sources and mobilizing new sources of private funding for resource conservation will allow for continuous capital accumulation whilst generating social benefits, such as new employment opportunities. Economic growth thinking rests thus upon the paradoxical combination of promised abundance and structural scarcity, in which desires are transformed into needs and needs are reduced to solvent demand (Rist 1996).

\section{A radical social-ecological transformation: actors, strategies and policies}

Degrowth implies a critique of 'commodification' or 'economization', that is the increasing "conversion of social products and socio-ecological services and relations into commodities with a monetary value" (Kallis et al. 2014:4). Commodification is a fundamental tool for making economic growth possible (Altvater 2012; Victor 2014). Escaping the 'tyranny' of economic growth means opposing economism as a thinking and behavioural paradigm and root ourselves in the terrain of the political (Fournier 2008). In doing so, we need to be attentive to micro- and macro-level transformations (Sekulova et al. 2013) and to challenge the imaginaries of instrumental rationality, consumerism, utilitarianism and productivism (Muraca 2013). In this regard, Kallis et al. (2014) have provided a review of practices, institutions and actors that might facilitate a degrowth transformation "to convivial societies who live simply, in common and with less" (ibid: 11). Non-capitalist grassroot economic practices including eco-communities, cooperatives, ethical banks, urban gardens, time banks and community currencies contribute to secure the basic needs of people relying on new processes of commoning with low material throughput. New welfare institutions such as an unconditional basic income, taxation on resources or resource caps, redistribution policies, job guarantee, socialization of care, public control over the creation of money, reduction of working hours and work sharing can secure a basic level of subsistence for all and liberate time from paid work, thus expanding voluntary and convivial activity and autonomy (Kallis et al. 2012, 2014). Care, education, health or environmental restoration can be the basis of a new, labour-intensive economy, prosperous without growth (see Jackson 2009). The role of the state is hence deemed crucial to facilitate the degrowth transformation through the implementation of 'non-reformist reforms.' 3 Socially sustainable degrowth should thus be conceived as a consequence of multiple strategies, ranging from oppositional activism to building alternative institutions to reforming some existing institutions, simultaneously implemented across multiple scales, from the local to the global (Demaria et al. 2013). In terms of actors, the evidence highlighted above suggests that activists, practitioners and researchers have played a key role in promoting degrowth, alongside policy makers, politicians, trade unionists and other lay citizens. What political subjects will be important in the future remains an open question.

\footnotetext{
${ }^{3}$ Giorgos Kallis and the Collective Research and Degrowth (2014) presented ten degrowth policy proposals in a press article entitled "Yes, we can prosper without growth" that was published by several mainstream European newspapers (see http://www.degrowth.org/yeswe-can-prosper-without-growth).
} 
There is a growing consensus among degrowth actors that degrowth involves a multi-scalar transformation beyond capitalism. In contrast to a marginal adjustment of economic and social systems resulting from multiple and overlapping crisis, the concept of transformation indeed "conveys something more radical than mere change or even transition to a new world" (Tschakert et al. 2013:346; Brown et al. 2012). The concept of transformation implies the need to go beyond pursuing or simply protesting against business-as-usual to actively constituting new meanings and practices. Radical diversion from existing pathways, as Burch and Harris (2014) assert, may only occur with intentional action in the realms of practice and policy, which O'Brien (2012) calls 'deliberate transformation', through the imagination of a post-capitalist future. This differentiates degrowth from previous approaches to sustainability based on a transitory or reformist pathway.

Therefore, the transformative nature of socially sustainable degrowth breaks with the political and cultural status quo and opens up spaces for new political and cultural imaginaries. Degrowth is both a critique of the ideology of growth (so-called 'decolonization of the imaginary', see Latouche 2014) and a proposal for an alternative desired direction. Transition discourses instead entail the persistence of pre-existing trajectories without changing the end goals (i.e. economic growth) and do not question the hegemonic neoliberal mode of governance (Brown et al. 2012). Incremental changes, the realm of sustainable development and mainstream sustainability thinking, may end up resulting in obstacles to sustainability by increasing investment in the existing system and narrowing down alternatives for change (Rickards and Howden 2012). Transition approaches fail to fundamentally rethink social structures, because they do not engage critically with the root causes of unsustainability.

However, we acknowledge that transformation is a concept with diverse, fragmented and, at times, contested meanings manifested at both agency (personal attitudes, political organization) and structure (institutions, socioeconomic arrangements) levels (Brown et al. 2013). Transformative approaches go far beyond keeping the main functions of a given socio-ecological system intact by adjusting to changing conditions (Brown et al. 2013). They aim instead to alter the fundamental attributes of a system, such as the economic mode of production, political institutions, ideologies, societal norms, everyday life, ecology (ibid; Brown et al. 2012) and so-called 'social natures', i.e. combined socio-ecological assemblages that are spatially, temporally as well as socially and materially produced, a result of power relationships and cultural meanings (Heynen et al. 2006; Swyngedouw and Heynen 2004). Transformations involve non-linear processes, because they deal with dynamic multidimensional and complex systems and understand social innovation as a key driving force of such processes (Brand et al. 2013). They involve multiple scales and system levels, from the local to the regional, national and international levels, and functional levels such as the markets, states and civil society (Brand et al. 2013).

\section{The contributions to this special feature}

This special feature brings together six contributions selected from papers presented at the Third and Fourth International Conferences on Degrowth for Ecological Sustainability and Social Equity (Venice 2012, and Leipzig 2014) and an ad hoc call for papers that we launched in August 2013. While early degrowth scholarly contributions were generally focused on problem diagnostics, i.e. "Why degrowth?" (Schneider et al. 2010; Saed 2012; MartinezAlier et al. 2010; Cattaneo et al. 2012), more recent debates have focused on the prognosis, i.e. "What needs to be done and how?" (D'Alisa et al. 2014; Sekulova et al. 2013; Kallis et al. 2012; Kosoy 2013). This special feature provides: first, some light on the discursive weaknesses of the sustainable development paradigm and on the economic and ecological implications of a global downscaling of resource and energy consumption; second, it provides new evidence on the actual practice of degrowth by analysing distinct political and social initiatives developed at distinct administrative and spatial scales, from local to regional and global levels. Overall, the articles shed light on some of the opportunities and challenges involved in the transformation that socially sustainable degrowth entails while contributing to challenge contemporary economic development narratives.

Gómez-Baggethun and Naredo open the collection of papers with a critical analysis of the shifting discourses on the relationship between growth and the environment in international sustainability policy. The authors review key policy documents from the publication of the Limits to Growth report and the celebration of the first Earth Summit in Stockholm (1972) to the celebration of the last Earth summit in Rio (2012). They identify three major discursive shifts in these policy documents over the studied period. First, whereas in the first years of international sustainability policy in the 1970 s, perpetual economic growth was considered the origin of environmental problems, it is now fully acknowledged as the solution to them. A key insight is that the concept of sustainable development, as presented by the 1987 Brundtland Report, played a key role in the restoration of growth as a desirable objective from an environmental and social point of view. Second, the authors identify a discursive shift from states and public regulation to private initiatives and market-based instruments as preferred means for addressing global ecological 
problems. Third, the politically committed tone of the first declarations in the 1970s-linking sustainability to equality, autonomy and cooperation, among other societal goals-gave way to the current technocratic approach where sustainability is presented as an apolitical problem to be tackled through technical fixes. The authors conclude that from the sustainable development consensus, sustainability principles have been over time re-shaped to fit dominant economic ideas, including the axiomatic necessity of unconstrained growth. These ideas, they argue, have to be broken down to move towards a radical turn in international sustainability policy that effectively tackles the roots of ecological and social degradation. A critical question for future research and action concerns whether and how the degrowth movement can help in this endeavor.

Capellán-Pérez et al. address the potential limits of global economic growth by applying a system dynamics global model that allows economic, energy and climate dynamics to be analysed in an integrated way under different socioeconomic alternatives. Their results suggest that expanding the use of coal as a means to maintain global economic growth in the future would not only be unfeasible due to supply limits, but also undesirable because of the climate impacts that would unfold during the next decades. Subsequently, they explore the economic and energy implications of an anticipated democratic collective shift towards a smaller and equitable economy which does not depend on economic growth. Some guidelines are derived for such a transformation including: the prompt application of strong sustainable and transition energy policies, the decrease of around $10 \%$ in global total primary energy demand, a radical transformation of the transportation sector and equal sharing of the total primary energy supply per capita. In terms of GDP, such a transition would imply a global convergence to the current world average level, whereby industrialized countries would reduce their per capita GDP four times while the Southern countries would increase it threefold. The transition would also require that the most energy-intensive countries should reduce their current per capita energy consumption by $70 \%$ to allow the least energy-intensive ones to increase it by $30 \%$.

Gerber's is the first of three papers providing insights on new forms of practising degrowth. He offers a preliminary overview of the main types of local credit systems, ascertaining their possible role in the degrowth transformation. $\mathrm{He}$ evaluates classical credit systems and modern credit alternatives to highlight their relevance for socially sustainable degrowth. He argues that post-growth-friendly credit arrangements should also consider the use of alternative forms of money, because the money we use on a daily basis has been created by commercial banks through credit and as such it creates constant pressures towards growth. He thus proceeds with an evaluation of local credit systems based on alternative money, from negative interest credit to social credit and mutual credit. He finds that the transformation towards a post-growth credit system apt for degrowth should go through different stages and levels. At the community level, local mutual credit systems could integrate the national currency and represent a good starting point for the degrowth transformation. At the national level, a Douglasian-type social credit scheme (with universal basic income and ticketing system) combined with a large-scale socialization of investment credit would cancel much of the routine needs for credit.

Kunze and Becker discuss the role that small-scale renewable energy cooperatives can play in a degrowth social-ecological transformation, thus enriching emerging debates about economic democracy and cooperativism within the degrowth literature (Johanisova and Wolf 2012; Johanisova et al. 2013). The authors define a new concept that would be able to embody such a challenge through its embedded normative goals: collective and politically motivated renewable energy projects (CPE). The political motivation rests on a participatory and democratic organisational structure combined with collective legal ownership and collective benefit allocation mechanisms. CPEs also include at least one of the following normative goals: an overall reduction of energy consumption, the protection of biodiversity, sustainable agriculture, a transition town agenda or more social equity and the empowerment of disadvantaged groups. Starting from an European survey on renewable energy projects, the study further narrows down the research scope upon sixteen projects, where indepth interviews are carried out, and presents the results of four emblematic cases from Wales, Italy, Spain and Germany. The cases analysed show that CPE can involve an upscaling movement, growing beyond the niche in which they emerged. The authors argue that if CPEs and alternatives more generally emerge at multi-scalar levels, they could embody a transformational potential beyond capitalism.

Missoni deals with health, an almost neglected topic within degrowth scholarship (an exception is Borowy 2013). While acknowledging the important role of community action for local change and individual lifestyle changes, Missoni argues that these experiences would fail if not embedded in a global governance system aiming at correcting socioeconomic determinants of health. The author argues that trade liberalization and deregulation processes intensified the commodification and commercialization of vital social determinants of health, affecting it through a variety of mechanisms, including changes in lifestyles, environmental degradation, reduced human security, privatization and commercialization of health care. Further, global public-private partnerships allowed 
private interest to influence global and national health policies. In this regard, the author uses two case studies from the food and tobacco industries to exemplify the need for public regulation in contrast to corporate practices inducing unhealthy lifestyles, and he highlights the importance of transnational social movements in pushing the prioritization of health and equity goals in policymaking. The author advocates for a more comprehensive analysis of the relations between health and degrowth, which should extend beyond medicine and health-care systems to focus also on the social determinants of health and the study of how such determinants might change during and after the transformation advocated by degrowth. According to Missoni, health policy in the context of degrowth should be governed by the principle of 'doing better with less' (Benatar 2013), i.e. focusing on the promotion of healthy lifestyles and choices, the control of medical consumerism and a more cautious use of technological resources in health services. Missoni argues that the World Health Organisation can potentially play an important role in promoting these changes in health governance through, for example, international standards or a new legally binding global health treaty.

The special feature ends with a review article by Escobar who situates degrowth and post-development theory within the larger context of transition discourses. He presents an overview of transition discourses and initiatives. Then he pays attention to the resurgence of postdevelopment debates in Latin American social movements through notions such as 'Buen Vivir'. The author underscores that both degrowth and post-development theory challenge the centrality of development, capitalism, market and growth in economic and cultural representations; they share intellectual sources and converge in the link between ecology and social justice; and they are aimed towards radical societal transformations. Escobar also argues that both approaches can learn from each other in a number of critical issues. For example, degrowth could emulate some of the post-development epistemic practices in which local knowledges are central to cross-scale political and economic changes, while post-development could create scholarly networks similar to those of degrowth to gain greater impact on academic circles. Post-development scholars' interest in biocentrism and non-dualist approaches could be a fruitful input to develop in greater depth the critique to modernity embedded in degrowth thinking, whereas degrowth's notion of conviviality could be helpful to advance a critique to over-consumption in the global South. Finally, Escobar stresses the importance for transition discourses to move away from a view of globalization as the universalization of modernity and adopt instead a view of globality as the struggle to preserve and foster the 'pluriverse'.
The articles together make evident that degrowth aims at re-embedding the economy within local communities and environments by means of re-localization and self-reliance through grassroot innovations and alternatives, and at the same time it is aware that such practices are insufficient for the transformation required unless major shifts in national and supra-national political and economic structures also take place. Additionally, the articles implicitly suggest that 'the local' is not contained or mobilized as a form of 'militant particularism' (Harvey 1996): radical localizers do not argue against connections out of the locality per se (such as in the form of networks), but argue against reification of connections as always inevitable and good, thus emphasizing the 'materiality' of scale (North 2005, 2010).

\section{Repoliticizing the science and practice of sustainability}

In the opening article of this journal, Komiyama and Takeuchi (2006) regretted the political biases of the concept of sustainable development, to which sustainability science is inextricably linked (Kates et al. 2001). Such biases, they argued, raised concerns about the solidity of its scientific basis, which remained unclear to many (Komiyama and Takeuchi 2006). For degrowth, the weakness of sustainable development as a truly transformative concept directly stems from its falsely consensual nature (Hornborg 2009). Degrowth unveils the ideological role of capitalist growth (Purdey 2010) and opens up the debate about the relations between economy, society and sustainability, including their cognitive, material and political interactions. In other words, degrowth helps to further emphasize the existing contradictions between growth, the environment and social well-being, and envisions a potential multi-scalar transformation pathway towards smaller and localized economies that redistribute wealth, supported by state and supra-national policies. In doing so, degrowth aspires to repoliticize the debates on the science and practice of sustainability.

It has been suggested that sustainability scientists have embraced a 'thin sustainability' concept_- "meeting human needs, both now and in the future, without degrading the planet's life support systems" (Miller 2013:283). Such a definition encourages widespread agreement, but limits the degree to which deeper discussions over a 'thick sustainability' and what it might mean to different people in different contexts take place (Miller 2013). By providing a thicker meaning of sustainability, degrowth re-politicizes the debate and asks the following question: If we are to guarantee a sustainable and just future for present and future generations, why should our economies grow? 
Almost 15 years after sustainability science was coined as a new scientific endeavour (Kates et al. 2001), the problems it aims to address have not diminished but exacerbated. The mismatch between a growing scientific field and effective and sustainable social-ecological change can be explained by different factors, including insufficient scientific engagement with stakeholders, anachronistic academic institutions and incentives, lack of meta-studies making transdisciplinary sustainability research available to scholars and practitioners and, in general, a missing link between knowledge production and action (Wiek et al. 2012; van der Leeuw et al. 2012; Kauffman and Arico 2014; Miller et al. 2014). Accordingly, ways forward have been advanced including fundamental reforms in the academy, more comparative studies making sustainability insights accessible and applicable, and a new social contract between scientists and society in which scientists participate in the co-production of knowledge for action with other stakeholders (Wiek et al. 2012; Kauffman and Arico 2014; Wittmayer and Schäpke 2014). Important as these factors may be, we argue that if they are not articulated into a broader critique of the fundamental underpinnings of our societies, such as that offered by degrowth and other transformation approaches (Escobar 2015, this feature), sustainability science is unlikely to meaningfully inform the social-ecological transformation required to confront the global environmental crisis. Uncovering the ideology and practice of economic growth (connected to capitalism) as the ultimate driver of unsustainability may help sustainability science to further flourish and be more influential in re-defining the Earth's sustainable future.

Acknowledgments Jonas $\emptyset$. Nielsen provided helpful comments to an earlier draft of the paper. We acknowledge the financial support of the Spanish government through the project BEGISUD "Beyond GDP growth: Investigating the socio-economic conditions for a Socially Sustainable Degrowth" (CSO2011-28990). EC has also been supported by the Spanish Research, Development and Innovation Secretariat through a "Ramón y Cajal" research fellowship (RYC2010-07183).

\section{References}

Altvater E (2012) Crecimiento económico y acumulación de capital después de Fukushima. Ens FEE 33(1):7-32

Asara V, Profumi E, Kallis G (2013) Degrowth, democracy and autonomy. Environ Values 22:217-239

Ayres RU, Ayres LW, Warr B (2004) Is the US economy dematerializing? Main indicators and drivers. In: van den Bergh JCJM, Janssen MA (eds) Economics of industrial ecology. Materials, structural change, and spatial scales. MIT Press, Cambridge, pp 57-93

Benatar SR (2013) Global health and justice: re-examining our values. Bioethics 27(6):297-304
Bonaiuti M (2008) Introduzione. In: Bonaiuti M (ed) Obiettivo decrescita. Editrice Missionaria Italiana, Bologna

Bonaiuti M (2013) La grande transizione. Dal declino alla societá della decrescita. Bollati Boringhieri, Torino

Borowy I (2013) Degrowth and public health in Cuba: lessons from the past? J Clean Prod 38(C):17-26

Boulding KE (1966) The economics of the coming spaceship earth. In: Jarrett $\mathrm{H}$ (ed) Environmental quality in a growing economy: essays from the sixth RFF forum. John Hopkins University Press, Baltimore

Brand U, Wissen M (2012) Global environmental politics and the imperial mode of living: articulations of state-capital relations in the multiple crisis. Globalizations 9(4):547-560

Brand U, Brunnengräber A, Omann I, Schneidewind U, Andresen S, Driessen P, Haberl H, Hausknost D, Helgenberger S, Hollaender K, Læssøe J, Oberthür S (2013) Debating transformation in multiple crises. In: World Social Science Report 2013: Changing Global Environments. ISSC, UNESCO, Paris

Brown G, Kraftl P, Pickerill J, Upton C (2012) Holding the future together: towards a theorisation of the spaces and times of transition. Environ Plan A 44:1607-1623

Brown K, O’Neill S, Fabricius C (2013) Social science understandings of transformations. In: World social science report 2013: changing global environments. ISSC, UNESCO, Paris, pp 100-106

Burch Sarah L, Harris Sara E (2014) Understanding climate change: science, policy, and practice. University of Toronto Press, Toronto

Cattaneo C, D'Alisa G, Kallis G, Zografos C (2012) Degrowth futures and democracy. Futures 44(6):515-523. doi:10.1016/j.futures. 2012.03.012

Chancel L, Demailly D, Waisman H, Guivarch C (2013) A postgrowth society for the 21 st century. In: Does prosperity have to wait for the return of economic growth? Studies no 08/13, Iddri, Paris, France

Dale G (2012) The growth paradigm: a critique. Int Soc 134

Dale G, Mathai MV, Puppim de Oliveira JA (2015) Green growth: ideology, political economy and the alternatives. Zed Books, London

D'Alisa G, Demaria F, Kallis G (eds) (2014) Degrowth. A vocabulary for a new era. Routledge. Taylor and Francis, New York

Demaria F, Schneider F, Sekulova F, Martinez-Alier J (2013) What is degrowth? From an activist slogan to a social movement. Environ Values 22(2):191-215

Deriu M (2008) Una rivoluzione dell'immaginario. In: Bonaiuti M (ed) Obiettivo decrescita. Editrice Missionaria Italiana, Bologna

Dietz R, O'Neill D (2013) Enough is enough: building a sustainable economy in a world of finite resources. Routledge, New York

Duverger T (2011) La décroissance, une idée pour démain : une alternative au capitalisme : synthèse des mouvements. Sang de la terre, Paris

Easterlin RA (1974) Does Economic Growth Improve the Human Lot? In: David PA, Readers MW (eds) Nations and households in economic growth: essays in honour of moses abramovitz. Academic Press, New York

Escobar A (2015) Degrowth, postdevelopment, and transitions: a preliminary conversation. Sustain Sci. doi:10.1007/s11625-0150297-5

Fioramonti L (2013) Gross domestic problem: the politics behind the world's most powerfull number. Zed Books, London

Flipo F (2007) Voyage dans la galaxie décroissante. Mouvements 50(2):143-151

Fournier V (2008) Escaping from the economy: the politics of degrowth. Int J Soc Soc Policy 28(11/12):528-545. doi:10.1108/ 01443330810915233 
Galeotti M, Lanza A, Pauli F (2006) Reassessing the environmental Kuznets curve for $\mathrm{CO}_{2}$ emissions: a robustness exercise. Ecol Econ 57(1):152-163

Georgescu-Roegen N (1971) The entropy law and the economic process. Harvard University Press, Cambridge

Georgescu-Roegen N (2009) Bioeconomia: verso un'altra economia ecologicamente e socialmente sostenibile. Bollati Boringhieri, Torino

Gómez-Baggethun E, Naredo JM (2015) In search of lost time: the rise and fall of limits to growth in international sustainability policy. Sustainab Sci. doi:10.1007/s11625-015-0308-6

Gorz A (1975) [1978]. Ėcologie et politique. Éditions du Seuil, Paris

Gorz A (1991) Capitalisme, socialism, écologie. Éditions Galilée, Paris

Gorz A (2009) Ecologica. Jaca Books, Milano

Grinevald J (2008) Georgescu-Roegen, bioeconomia e biosfera. In: Bonaiuti M (ed) Obiettivo decrescita. Editrice Missionaria Italiana, Bologna

Gudynas E (2011) Buen vivir: today's tomorrow. Development 54(4):441-447

Haas W, Krausmann F, Wiedenhofer D, Heinz M (2015) How circular is the global economy?: an assessment of material flows, waste production, and recycling in the European union and the world in 2005. J Ind Ecol. doi:10.1111/jiec.12244

Hamilton C (2004) The growth fetishism. Pluto Press, London

Harvey D (1996) Justice, nature and the geography of difference. Blackwell, Oxford

Harvey D (2014) Seventeen contradictions and the end of capitalism. Oxford University Press, Oxford

Helliwell J, Layard R, Sachs J (2012) World happiness report. Earth Institute, Columbia University

Heynen N, Kaika M, Swyngedouw E (2006) In the nature of cities. Urban political ecology and the politics of urban metabolism. Routledge, London

Hornborg A (2009) Zero-sum world. Int J Comp Sociol 50(3-4):237-262

Illich I (1973) Tools for conviviality. Fontana/Collins, Glasgow

Illich I (1978) Towards a history of needs. Panthéon, New York

IMF (International Monetary Fund) (2015) Where are we headed? Perspectives on potential output, Ch. 3. In: World economic outlook. Uneven growth: short- and long- term factors. IMF, Washington DC, pp 69-110

Jackson T (2009) Prosperity without growth. Earthscan, London

Johanisova N, Wolf S (2012) Economic democracy: a path for the future? Futures 44(6):562-570. doi:10.1016/j.futures.2012.03.017

Johanisova N, Crabtree T, Fraňková E (2013) Social enterprises and non-market capitals: a path to degrowth? J Clean Prod 38:7-16. doi:10.1016/j.jclepro.2012.01.004

Kallis G, Martinez-Alier J, Norgaard RB (2009) Paper assets, real debts: an ecological-economic exploration of the global economic crisis. Crit Perspect Int Bus 5(1/2):14-25. doi:10.1108/ 17422040910938659

Kallis G, Kerschner C, Martinez-Alier J (2012) The economics of degrowth. Ecol Econ 84:172-180. doi:10.1016/j.ecolecon.2012. 08.017

Kallis G, Demaria F, D'Alisa G (2014) Introduction: degrowth. In: D'Alisa G, Demaria F, Kallis G (eds) Degrowth: A vocabulary for a new era. Routledge, London

Kapp KW (1961) Toward a science of man in society: a positive approach to the integration of social knowledge. Martinus Nijhoff, The Hague

Kapp KW (1970) Environmental disruptions and social costs: a challenge to economists. Kyklos 23:833-847

Kates RW, Clark WC, Corell R et al (2001) Sustainability science. Science 292(5517):641-642
Kauffman J, Arico S (2014) New directions in sustainability science: promoting integration and cooperation. Sustain Sci 9:413-418

Klitgaard K (2013) Heterodox political economy and the degrowth perspective. Sustainability 5(1):276-297. doi:10.3390/ su5010276

Komiyama H, Takeuchi K (2006) Sustainability science: building a new discipline. Sustain Sci 1:1-6

Kosoy N (ed) (2013) Degrowth: the economic alternative for the anthropocene, special issue. Sustainability 5

Kothari A (2014) Radical ecological democracy: a path forward for India and beyond. Great transition. http://www.greattransition. org/publication/radical-ecological-democracy-a-path-forward-forindia-and-beyond. Accessed 29 June 2015

Kothari A, Demaria F, Acosta A (2015) Buen vivir, degrowth and ecological swaraj: alternatives to development and the green economy. Development (forthcoming)

Krausmann F, Gingrich S, Eisenmenger N, Erb KH, Haberl H, Fischer-Kowalski M (2009) Growth in global materials use, GDP and population during the $20^{\text {th }}$ century. Ecol Econ 68(10):2696-2705

Krugman P (2014) Errors and emissions. Could fighting global warming be cheap and free? The New York Times, 18 Sept. http://www.nytimes.com/2014/09/19/opinion/paul-krugmancould-fighting-global-warming-be-cheap-and-free.html?_r=1. Accessed 29 June 2015

Latouche S (2008) Breve trattato sulla decrescita serena. Bollati Boringhieri Editore, Torino

Latouche S (2009) Farewell to growth. Polity Press, Cambridge

Latouche S (2011) Come si esce dalla società dei consumi. Corsi e percorsi della decrescita. Bollati Boringhieri, Torino

Latouche S (2013) Prefazione. In: Bonaiuti M (ed) La grande transizione: Dal declino alla società della decrescita. Bollati Boringhieri, Torino

Latouche S (2014) Imaginary, decolonization of. In: D'Alisa G, Demaria F, Kallis G (eds) Degrowth: a vocabulary for a new era. Routledge, London

Martinez-Alier J (2012) Environmental justice and economic degrowth. An alliance between two movements. Capital Nat Social 23(1):51-73

Martinez-Alier J (2014) Environmentalism, currents of. In: D'Alisa G, Demaria F, Kallis G (eds) Degrowth: a vocabulary for a new era. Routledge, London

Martinez-Alier J, Pascual U, Vivien F, Zaccai E (2010) Sustainable de-growth: mapping the context, criticisms and future prospects of an emergent paradigm. Ecol Econ 69:1741-1747. doi:10. 1016/j.ecolecon.2010.04.017

Meadows DH, Meadows DL, Randers J (1972) Limits to growth. Universe books, New York

Metz T (2011) Ubuntu as a moral theory and human rights in South Africa. Afr Hum Rights Law J 11(2):532-559

Miller TR (2013) Constructing sustainability science: emerging perspectives and research trajectories. Sustain Sci 8:279-293

Miller TR, Wiek A, Sarewitz D et al (2014) The future of sustainability science: a solutions-oriented research agenda. Sustain Sci 9:239-246

Mouffe C (2005) On the political. Routledge, London

Muraca B (2013) Décroissance: a project for a radical transformation of society. Environ Values 22(2):147-169. doi:10.3197/ $096327113 X 13581561725112$

Muraca B (2014) Between doom and utopia: Degrowth as a way out of the crisis? In: Speech given at the fourth international conference on degrowth for ecological sustainability and social equity, 2-6 September 2014

Neef M (1995) Economic growth and quality of life: a threshold hypothesis. Ecol Econ 15(2):115-118 
North P (2005) Scaling alternative economic practices? Some lessons from alternative currencies. Trans Inst Br Geogr 30:221-233

North P (2010) Eco-localization as a progressive response to peak oil and climate change-a sympathetic critique. Geoforum 41:585-594

O'Brien Karen (2012) Global environmental change II: from adaptation to deliberate transformation. Prog Hum Geogr 36(5):667-676

O'Connor J (1998) Natural causes: essays in ecological marxism. The Guilford Press, New York

Odum HT, Odum EC (2001) [2008] A prosperous way down. University Press of Colorado, Boulder

Philipsen D (2015) The little big number: how GDP came to rule the world and what to do about it. Princeton University Press, Princeton

Pickett K, Wilkinson R (2009) The spirit level. Why equality is better for everyone. Penguin Books, London

Piketty T (2014) Capital in the twenty-first century. Belknap Press, Cambridge

Polimeni J, Mayumi K, Giampietro M, Alcott B (2007) The jevons paradox and the myth of resource efficiency improvements. Earthscan, New York

Pope Francis (2015) Encyclical letter laudato si'. On care for our common home. http://w2.vatican.va/content/francesco/en/ency clicals/documents/papa-francesco_20150524_enciclica-laudatosi.html. Accessed 29 June 2015

Purdey SJ (2010) Economic growth, the environment and international relations: the growth paradigm. Routledge, New York

Rickards Lauren, Howden Mark S (2012) Transformational adaptation: agriculture and climate change. Crop Pasture Sci 63(3):240-250

Rist G (1996) [2008] History of development. From Western origins to global faith. Zed Books, London

Saed (2012) Introduction to the degrowth symposium. Cap Nat Soc 23(1):26-29. doi:10.1080/10455752.2011.648836

Schneider F, Kallis G, Martinez-Alier J (2010) Crisis or opportunity? Economic degrowth for social equity and ecological sustainability. J Clean Prod 18:511-518

Sekulova F, Kallis G, Rodríguez-Labajos B, Schneider F (2013) Degrowth: From theory to practice. J Clean Prod 38:1-6. doi:10. 1016/j.jclepro.2012.06.022

Sorman A, Giampietro M (2013) The energetic metabolism of societies and degrowth paradigm: analyzing biophysical constraints and realities. J Clean Prod 38:80-93
Soumyananda D (2004) Environmental Kuznets curve hypotesis: a survey. Ecol Econ 49(4):431-455

Steffen W, Richardson K, Rockström J et al (2015) Planetary boundaries: guiding human development on a changing planet. Science 347:6223

Stern D (2004) The rise and fall of the environmental Kuznets curve. World Dev 32(8):1419-1439

Summers L (2013) Why stagnation might prove to be the new normal. Financial times. http://www.ft.com/cms/s/2/87cb15ea-5d1a11e3-a558-00144feabdc0.html. Accessed 26 May 2015

Swyngedouw E (2007) Impossible/undesirable sustainability and the post-political condition. In: Krueger JR, Gibbs D (eds) The sustainable development paradox. Guilford Press, New York, pp 13-40

Swyngedouw E (2014) Depoliticization ('the political'). In: D'Alisa G, Demaria F, Kallis G (eds) Degrowth: a vocabulary for a new era. Routledge, London

Swyngedouw E, Heynen NC (2004) Urban political ecology, justice and the politics of scale. Antipode 35(5):898-918. doi:10.1111/j. 1467-8330.2003.00364.x

Teulings C, Baldwin R (2015) Secular stagnation: facts, causes and cures. CEPR Press, London

Tschakert P, van Oort B, St. Clair AL, LaMadrid A (2013) Inequality and transformation analyses: a complementary lens for addressing vulnerability to climate change. Clim Dev 5(4):340-350

UNEP (United Nations Environmental Program) (2011) Decoupling natural resource use and environmental impacts from economic growth. In: Fischer-Kowalski M, Swilling M, von Weizsäcker EU, Ren Y, Moriguchi Y, Crane W, Krausmann F, Eisenmenger N, Giljum S, Hennicke P, Romero Lankao P, Siriban Manalang A (eds) Report of the working group on decoupling to the international resource panel. UNEP, Nairobi

van der Leeuw S, Wiek A, Harlow J et al (2012) How much time do we have? Urgency and rhetoric in sustainability science. Sustain Sci 7:115-120

Victor PA (2014) Growth. In: D’Alisa G, Demaria F, Kallis G (eds) Degrowth: a vocabulary for a new era. Routledge, London

Wiek A, Farioli F, Fukushi K et al (2012) Sustainability science: bridging the gap between science and society. Sustain Sci 7:1-4

Wittmayer JM, Schäpke N (2014) Action, research and participation: roles of researchers in sustainability transitions. Sustain Sci 9:483-496 